\title{
$\mathbb{Z}$ Muke $\mathfrak{Z}$ am $\mathfrak{J}$ ournal
}

VOLUME I962

WINTER

NUMBER I

\section{LAW DAY SYMPOSIUM: STRATEGY AND TACTICS IN TAX CASES}

\author{
Leon L. Rice, JR., Chairman* \\ J. Carlton Fleming, Panelist \\ Hugh G. Istey, JR., Panelist京 \\ Numa L. Smith, Panelist§
}

"Strategy and Tactics in Tax Cases" is a panel discussion which took place at the annual observance of Law Day at the Duke University School of Law last Spring. Four distinguished tax practitioners, all of whom are alumni of the Law School, undertook to explore some of the procedural problems connected with a tax case. The object of the discussion was to present the procedural steps in a tax case with sufficient simplicity to appeal to the general practitioner, and, at the same time, to probe deeply enough into strategic and tactical considerations to titillate the more sophisticated palate of the tax specialist. There were no formal papers. After conferring together, the panelists, aided by their notes, talked almost extemporaneously;

*A.B., 1933, Furman University; LL.B., 1936, Duke University. Attorney in Office of Chief Counsel, Bureau of Internal Revenue, Washington, D.C., 1937-40; Member, North Carolina and South Carolina Bars; Member, Council and Secretary of Section on Taxation, American Bar Association, 1949-52; Member, American Law Institute. Author and contributor to legal periodicals. Practicing attorney, Winston-Salem, North Carolina.

† A.B., 1949, LL.B., 1951, Duke University; LL.M., 1953, George Washington University. Membex, North Carolina Bar; Member, North Carolina and American Bar Associations. Practicing attorney, Charlotte, North Carolina.

¥A.B., I951, LL.B., 1953, Duke University. Former trial attorney, Office of Chief Counsel, Internal Revenue Service, Atlanta, Georgia; Member, North Carolina and Florida Bars. Practicing attorney, Raleigh, North Carolina and Fort Lauderdale, Florida.

§ A.B., 1938, Furman University; LL.B., I941, Duke University. Member, District of Columbia Bar; Member, Federal and American Bar Associations. Member, American Law Institute. Practicing attorney, New York, New York and Washington, D.C. 
their words were recorded on tape. With some editing, which has been consciously restrained in an effort to preserve the flavor of the original proceedings, the discussion by the panel is presented on the following pages.

$\mathrm{M}^{\mathrm{s}}$ R. RICE: Our subject, "Strategy and Tactics in Tax Cases," is a very broad one. We are going to limit our discussion to income tax cases with "proposed deficiencies, although most of our remarks will also be applicable to refund cases. Our remarks also will bear in large measure upon estate and gift tax procedure. In our preliminary discussion, we will talk in terms of a case which involves no issue of fraud, either civil or criminal. At the conclusion, we will undertake to point out some special considerations that might be applicable in fraud cases.

The dictionary indicates that strategy and tactics are military terms, which are defined generally as the science of planning and directing large scale military operations. Of course, these terms have come to have much broader connotations in everyday language, and we are using them in this broader sense. We do not regard strategy and tactics as being a "cat and mouse" game with the Internal Revenue Service, but we think of it in terms of what we can justly do to represent our clients most effectively in matters involving income taxes. We certainly want to adhere to high ethical and professional standards and do not wish to take unfair advantage of the other side. Nevertheless, the fact that here we are talking about an adversary situation must not be overlooked. The Government in a tax case is an adversary to the interested taxpayer, and government men are well aware of their adversary position.

The matter of strategy and tactics in tax cases ideally begins when a transaction which might be questioned by the Revenue Service is being planned. In making the decisions involved in tax strategy and tactics, experience is the best teacher. Moreover, the human element is of utmost importance, and knowing the man with whom you are negotiating is very helpful. If you don't know your opposite from previous associations, then perhaps you can inquire about him, for the more you know about him, the better you will be able to deal with him. The business of strategy and tactics also involves elements of "horsetrading," but it should be on a sound basis and not on a purely foolish or illusory one.

Now, with those preliminary remarks, let's take a close look at tax procedure. In other words, how does this case come about and how do 
you handle it through the Revenue Service and perhaps up to the courthouse door? Our tax system is a system of self-assessment, based upon the basic honesty of the taxpayer, who must make out his return and file it with the Government. After a return is filed, the Government may choose to select the return for audit. At present, returns are selected for examination on a number of criteria; but generally speaking, the larger the income, the more likely is the return to be selected. In addition, particular types of taxpayers are often singled out for investigation, such as lawyers, doctors, or restaurant operators. ${ }^{1}$ If, in violation of law, no return is filed, governmental action is contingent on discovery of this violation. The Government has at its disposal quite a few sources of information whereby it may check the accuracy of a return or decide whether it should be specially audited. A few of these are the information returns that are filed by payors of various kinds of income, partnership returns and interchanges of information with state revenue agencies. For example, there is in North Carolina an interchange of information; and this can be very helpful to both the federal and state authorities. One new factor which will have a significant effect on the checking and examining of returns is automatic data processing, referred to as A.D.P. ${ }^{2}$ By utilization of electronic computers, magnetic tapes and centralized collection and comparison of data, the electronic "brains" eventually will have the capacity to trace virtually every transaction in the economy to the ultimate taxpayer. This is doubtless going to be very effective and helpful to the Revenue Service. Furthermore, many new revenue agents are being employed. More revenue agents mean more examinations and thus more tax cases to be handled.

After a return has been selected by the Revenue Service for examination, it is assigned to a revenue agent. This agent is the first government representative to contact the taxpayer. As the taxpayer's representative, you are entitled to talk with this agent, and you may settle the case at this stage. If settlement is not reached, you will be given an opportunity for what is called an "informal conference," which is handled very informally with the revenue agent and a con-

\footnotetext{
${ }^{1}$ Whenever a taxpayer's daily transactions are conducted primarily in cash, his return will attract more careful scrutiny by the Service. See, LORE, How to WIN A TAX CASE 23 (1955).

${ }^{2}$ For a brief discussion of automatic data processing as it will work for the Internal Revenue Service, see Caplin, Automatic Data Processing of Federal Tax Retums, PRAC. LAW., Oct. 1961, p. 43.
} 
feree. If the case is big or fairly complex the conference coordinator in the District Director's office may replace the conferee. If there is no settlement at the informal conference level, a "30-day letter" will be received. This letter transmits the revenue agent's report to the taxpayer and gives a complete exposition of the government's position and the tax adjustments that have been proposed. At this point, a protest may be filed with the District Director. In this protest you can request a conference with a conferee from the Appellate Division, and this conference will be granted. If no settlement is made, the next step is the issuance of a statutory notice of deficiency, or "9o-day letter," which is the basis for fling a petition with the Tax Court. You will have an opportunity, as will be brought out later, to discuss settlement of the case even after the petition is filed and the case is in what is called "docketed status."

This is a brief outline of the procedural steps involved, and our workshop will proceed generally along these lines. Thus, we will first consider the question of strategy in planning transactions and handling them on the return.

$M_{R}$. SMITH: First in time and, in my opinion, first in importance, is the planning and testing of a transaction from the standpoint of its tax consequences. It is at this planning stage that the transaction assumes the characteristics with which the taxpayer and the taxpayer's representative will have to live.

However, a transaction can be overplanned, as the following contemplation of death case illustrates. A taxpayer, shortly before he made the gifts in question, went to his doctor who gave him a clean bill of health in writing. That course of action was questionable, but probably would not have been fatal. However, this particular taxpayer didn't leave well enough alone. He also requested that the doctor state in his letter that the taxpayer's health was such that he had no reason to contemplate death. This letter was submitted with the estate tax return. With such a letter in the government's file, arguing against a contemplation of death gift was useless. This transaction was overplanned and is not the type of planning I have in mind. The recommended type of planning is that which will give you, after a sufficiently careful examination of the transaction, reasonable confidence that you are aware of the points of danger and have dealt with them as best you can.

Let's assume that you have planned the transaction and are reason- 
ably satisfied as to its tax consequences. What can be done to give the client even more protection? This raises the question of whether the transaction is such that you can get a ruling from the Internal Revenue Service, and if so, whether you should apply for such a ruling. The Revenue Service, of course, gives rulings on some prospective transactions. In a recent fiscal year, there were over forty thousand applications for rulings, showing that many taxpayers take advantage of this service offered by the Treasury. The Revenue Service, however, will. not issue rulings on all types of prospective transactions. For example, the Service will not rule on essentially factual questions, such as the. reasonableness of compensation, the value of property, or the reasonableness of accumulated earnings of a corporation. Additionally, the Service refuses to issue rulings in certain areas because it believes that: the law is too uncertain, or if applied literally, that the law produces: unintended benefits, or because the transaction is in an area in which the Revenue Service's policy is not developed. Examples of these "noruling" areas are whether a corporation is "collapsible" and whether advances to a "thin" corporation are loans or equity investments. Revenue Procedure 60-63 identifies generally other types of problems: to which this "no ruling" policy applies.

If a transaction falls in an area in which the Service will rule, you must then decide whether you are going to advise the client that the transaction is such that it would be too risky for him to proceed without: a ruling. If the client agrees, the problem is simplified and you apply for a ruling. If the client is willing to take the chance, the question then is whether a ruling would be a good "insurance policy." In many types of transactions, particularly in corporate reorganizations, and other Subchapter $\mathrm{C}$ transactions, it probably is wise to get a ruling if you can. This is particularly true today because new issues are developing under the 1954 Code and it will be some time before agents become familiar with these issues and their treatment. On the other hand, if you know that the Service's attitude toward your type of transaction is unfavorable, little can be gained, and much can be lost, by applying for a ruling. If you don't know what the Revenue Service's attitude is, you can, by various ways, discover the Service's thinking on a particular point. For example, they will be happy to tell you if they have ruled. on a question before and if so how they ruled on it. Furthermore, the Service will give in some circumstances a "technical advice ruling"4.

\footnotetext{
1960-r Cum. Bull. 880.

Rev. Proc. 58-14, 1958-2 CuM. Buld. 1125.
} 
after the issue has been raised by the agent. If an agent raises an issue and you believe that other districts are treating this issue differently from the way the agent proposes to treat it, or if the issue is a complicated one, you can ask the agent to refer the issue to Washington for technical advice. The agent does not have to comply. However, the taxpayer can appeal the agent's refusal to the Chief, Audit Division, in the District's Director's office, who will decide whether the issue should be submitted to Washington. At that point, the taxpayer has exhausted his rights, but, as an internal matter, if the Chief, Audit Division, sides with the agent and decides not to refer the case to the national office, he must write the national office, telling them that the request has been made and giving his reasons for not referring the case as the taxpayer requested. The national office of the Internal Revenue Service encourages applications for technical advice. This is particularly true today, for the Service views the "technical advice ruling" as one means of achieving desired uniformity under the 1954 Internal Revenue Code. Of course, if you think that the national office is going to give an unfavorable answer, you certainly do not want to request technical advice.

Most rulings are issued by the national office. However, the Disstrict Director is authorized to issue "determination letters" on a prospective transaction in two situations: the question of qualification of a pension or profit-sharing plan, and applications for an exempt status of a charitable or other exempt organization under Section 501 of the Code. As to completed transactions where a return has not been filed, the District Director can issue a determination letter only if the answer is clear from the law, Regulations or published policy of the Service. ${ }^{\circ}$

Making an application for a ruling has some disadvantages. One is the delay involved in processing rulings, since each case has to be studied on its own. However, the national office is doing an outstanding job in issuing rulings with a minimum of delay. A major disadvantage is that once you apply for a ruling and the Service has substantially completed its study of the question involved, you cannot withdraw the application. However, you can ask the Service not to issue the ruling letter and they will abide by your request, but they will send the application and the results of their study to the District Director. Thus, you are almost in as bad a shape as if the Service had actually issued the unfavorable ruling.

\footnotetext{
${ }^{5}$ General Procedural Rules, 1955-2 Cum. BuLL, 92 I, 945-56.
} 
Now, let's assume that you have decided not to apply for a ruling, and you are consulted as to how to handle this transaction on the tax return. I am not advocating that attorneys should prepare the returns, but proper planning requires that you consider how to report the transaction on the return correctly.

Initially, you should decide whether this transaction will require some affirmative action on the return. For example, an election is required if you expect to report a sale of property on the installment basis. If some affirmative action is necessary, care should be taken to insure that the action is strictly in accordance with the Regulations or you might find that an election has not been made at all.

Another consideration is whether the disclosure of the transaction that you propose is sufficient to guard against any later charge of concealment. Thus, you must decide the extent of the reporting. There are some situations, primarily cases involving exchanges of stock pursuant to a corporate reorganization, where the Regulations ${ }^{6}$ require that an explanation be submitted with the return. Aside from these comparatively few situations, however, it is probably better to set out only the results of the transaction, explaining the details if and when such explanation becomes desirable. You should always keep in mind that anything adverse on the return can probably be used against the taxpayer.

Mr. RICE: To emphasize the importance of an attorney's being called in at the planning stage of a transaction, Mr. Fleming is going to point out a few of the tax problems involved in the sale of a business.

Mr. Fleming: Several questions are, from a practical viewpoint, very often of particular significance. For example, suppose you have a client who owns all the stock of a corporation. To him the corporation is just his business, and he doesn't consider that he is dealing with the legal entity of a corporation. He calls you and says, "I've sold my business for so many thousand dollars and I have been forced to agree that I will not compete in this business for a period of three years." Right there, as you can see, you have a significant tax question raised by a covenant not to compete. ${ }^{7}$ You have a direct conflict between the tax advantages and disadvantages of the seller and the buyer. If there is no allocation of a specific amount to the covenant not to compete, the

\footnotetext{
${ }^{\circ}$ E.g., Treas. Reg. $\S_{1.355-5}$ (1956).

'E.g., Hamlin's Trust v. Commissioner, 209 F.2d 761 (roth Cir. 1954).
} 
seller has a capital gain insofar as that portion of the transaction is concerned; whereas, if there is an allocation of a specific amount to the covenant, the seller has ordinary income for the amount of the allocation. Conversely, where there is no allocation, the buyer must capitalize that item and he has no opportunity to take a current deduction. If there is an allocation, he can deduct ratably the amount allocated to that covenant over the period of the covenant. Frequently you find that an informal arrangement on noncompetition has already been entered into which, depending upon whether you are representing the seller or the buyer, perhaps ought to be straightened out, because important tax consequences can result.

Another problem can arise when a client, who owns all the stock in a corporation, sells "his business." All he knows is that he is out of that business and as soon as he collects his money he's through with it. But has he agreed to sell the stock or the assets of the corporation? Under the old federal law and under the current North Carolina law, if the corporation sells the assets of the business, the corporation pays its tax on any excess of the consideration received over the basis of those assets. Then, when the client liquidates the corporation, a second tax must be paid on the difference between the basis of the stock he holds and the proceeds that he receives on liquidation. The Federal Government has now alleviated that problem by the passage of Section 337 of the I954 Code, which eliminates the payment of the first of those taxes if you comply with section 337 at the corporate level. But the State of North Carolina has not been so generous with its taxpayers, and practitioners often overlook this point. If the transaction is cast as a sale of assets followed by liquidation, there may be a substantial North Carolina income tax due, which could be avoided if the transaction involved a sale of the stock of the corporation or, alternatively, if the corporation were first liquidated and then the stockholder sold the assets.

Mr. RICE: It should be pointed out that sometimes taxpayers in general are hurt by other taxpayers who try to push a good thing too far. ${ }^{8}$ An example is the abuse of the deductions for travel and entertainment expenses with the result that there are now prospects of legislation in this field. Other examples might be the Pomona College plan, a

\footnotetext{
${ }^{8}$ Miller, The Taxpayer's Duty to his Fellow Taxpayer, 39 TAXEs 341 (196r), which is a condensation of an article in N.Y.U. 19th Inst. on Fed. Tax, was referred to at this point by Mr. Rice.
} 
charitable device involving tax exempt securities, and the so-called Centennial Fund situation, which is a device for swapping appreciated stocks for shares of a mutual fund tax free. The result of these devices is that now the Revenue Service won't rule in what they regard as "gimmick" situations." So, in formulating plans for your clients, consider whether you are part and parcel of pushing a good thing too far with the possible result that loopholes are going to be closed either by the courts or by Congress.

The next phase which is going to be covered deals with negotiating with the revenue agent.

Mr. Fleming: Tax cases are born in the Treasury Department's audit procedure. There may be any number of transgressions in the taxpayer's tax picture for a particular year, some disclosed on the return, some not disclosed, and in some instances no returns even being filed. No tax case exists, however, until the Treasury Department decides to make an audit. Because of this, some taxpayers assume the "ostrich complex" and conclude that with sixty-odd million returns to be processed, it's almost a mathematical impossibility that their return will be checked. However, the possibility of a return's being checked is greater than one might realize.

The Service now has automatic data processing machinery which examines almost every return for mathematical accuracy and for extraordinary deductions along certain lines. Furthermore, there has been an increase in the number of revenue agents which are available to make audits. Under existing procedures, the Revenue Service audits about half of the returns within certain categories. For example, the returns of individuals with income of more than $\$ 50,000$, or individuals with income of more than $\$ 25,000$, if they have self-employment business expenses, or if they are farmers, will be audited. Doctors are a classic example of a category from which the Revenue Service selects a high percentage of returns for audit. So, more and more people will find that although they had hoped their return would never be subjected to examination, one day a revenue agent will call and say, "I'd like an appointment" or will simply show up on the spot. For this reason, it is incumbent upon the lawyer, in the case of regular clients with whom he has such a relationship that he can ethically do this, to point out to his client that when he is informed of a proposed visit by a revenue agent or when the agent actually shows up in his office, he

\footnotetext{
${ }^{\mathrm{a}}$ Rev. Proc. 60-6, I960-1 Cum. Bulz. 880.
} 
should get in touch with the lawyer so that the proper planning of what is to come can begin immediately.

Certain information should be obtained by the client from the agent. The client should ask for the agent's identification, so that the client can determine that this fellow is really a revenue agent, and not a business competitor. He should note the agent's name and be able to give it to you when he calls because you may know the name of the agent and his speciality. His name will be your first indication as to whether you're dealing with an ordinary or a special agent. The difference between an ordinary and a special agent is somewhat akin to the difference between Little Red Riding Hood and the wolf, grandma being the taxpayer. If a special agent has contacted your client, the matter is under the jurisdiction of the Intelligence Unit. Agents of the Intelligence Unit have one primary function in the government's system of tax administration-to obtain information upon which a criminal case can be built which will result in a criminal conviction. We are going to defer discussion of the fraud element until later, but you cannot avoid it at this opening juncture. If it is evident that you have a special agent on the case, you must consider the matter as a fraud case, and treat it accordingly. On the other hand, just because an ordinary agent is conducting the investigation you can't conclude that you do not have a fraud case, because very often a fraud case begins with an examination by a regular agent who uncovers evidence which he considers indicative of fraud. Through channels the matter may reach the Intelligence Unit, which may assume jurisdiction, or perhaps, the regular agent will be directed to continue his investigation. The regular agent will then continue his audit and develop evidence on the fraud count. An Internal Revenue Service policy is that the regular agent should not go in as a front-runner for the special agent, but as a practical matter, very often a fraud case begins with the regular agent.

If a regular agent is on the case and thus you don't know whether there is a fraud investigation, you should immediately make two inquiries, although you may have a normal examination. First, what is the possibility of fraud? As any lawyer who has ever asked that question of a client knows, it's very difficult to get a candid answer. Your client may be a personal friend and he may have a high reputation in the community. Thus, he will be reluctant to admit that he's a crook. At times it is diffcult to get an admission from a client that there is even a possibility of a fraud count. In such cases, it is in 
cumbent upon the lawyer to point out to the client that an inquiry as to possible fraud is made for the client's own protection and if there is any possibility, no matter how slight, that a fraud investigation might ensue, the lawyer should be advised of it at the outset. Otherwise, the client's case unwittingly may be sacrificed by the disclosure of too much information when such information might not otherwise prejudice the client's case.

Second, what possible deficiencies or tax diffculties are there in the years which are being subjected to audit? At the outset, you should know as much as possible about the possibilities of additional tax difficulties. The taxpayer may be worried about five or six different possible issues in one of the years being audited. If the revenue agent raises one or two of these issues and overlooks the others, it is imperative that you be aware of the overlooked issues so that you can make proper settlement at a low level and avoid finding yourself at a higher level faced with large deficiency assessments that you had no idea were even in the case. For example, a lawyer was handling a case in which a $\$ 70,000$ deficiency was proposed and in the lower levels of negotiation the taxpayer tried hard to cut that $\$ 70,000$ back. The taxpayer finally decided to settle for $\$ 40,000$ and not a cent more. The case went to the Appellate Division. When the Appellate Division looks a case over, you can expect more experience and greater all-around ability. Appellate found a $\$ 200,000$ deficiency. As you can imagine, it was quite a shock to that lawyer, who had a chance to settle the case for $\$ 70,000$ on certain issues, to find that the Government had come up with other issues which turned his $\$ 70,000$ case into a $\$ 200,000$ case. It's extremely important to bring all the problems and all the possible deficiencies to the surface as early as you can. Otherwise, if the agent picks up one or two points there is a great tendency for the lawyer to get so involved in the contested points that he never thinks of going back to see if there are other, perhaps greater, monetarily speaking, questions involved in the return.

With the exception of fraud cases, it is not normally necessary, or even advisable, for the lawyer to be involved with the revenue agent while the agent is making an audit of the books. There usually is no need for the lawyer to work directly with the agent until he is ready to make his proposed findings. Certainly, however, the lawyer should give advice to his client on what might be termed the "care and feeding" of revenue agents. First of all, he ought to be made comfortable. Mr. Smith has an amusing example of how this should not be done. 
Mr. SMITH: In the situation I have in mind, the agent was made quite comfortable. However, each time he requested information from the taxpayer, he was invited out to lunch or for coffee. This went on for well over a year. Finally, the agent became aware that he was not going to get any information, so he decided all the points against the taxpayer.

Mr. Fleming: The point here is that the revenue agent expects to have a comfortable place to work and expects not to have too much difficulty in obtaining information. This does not mean, however, that you ought to advise your client to volunteer any information that he can dream up. Perhaps the best procedure is for the principal involved, for instance, the president of the corporation in question, to keep away from the revenue agent as much as possible. There's no advantage in having him right at the agent's elbow so that every time a question occurs to the agent he can turn and say, "Well now, Mr. Jones, what did you take this trip for?" or ask other specific questions peculiarly within the knowledge of the company president. It's a much better procedure to have the bookkeeper, the accountant, the controller, or someone who has limited knowledge work with the revenue agent so that the agent will have to go somewhere else to get the answers to his questions. The client should not distort the answer or dream up one, but at times he can phrase it better if he has a little time to think about it. Also, it is good advice not to have anyone hover over the revenue agent during the'time he's making his audit. One who hovers is going to answer a lot more questions than would be required if the agent found it necessary to note the questions as they occurred to him and then get the answers when he sees the client's representative later.

Another point about which the client ought to be forewarned is that the revenue agent is going to make voluminous notes. For instance, when the agent examines the president of the company, he will make notes of everything the president says and later dictate a memorandum from those notes. Naturally, when the agent dictates his memorandum, it will be in a light most favorable to the government's position. If you eventually get into litigation, you may be confronted with that memorandum of what your client said three years or so ago in the course of an audit. The revenue agent has it all written down, but the corporation president has no written record. If you ask your client if he ever made such a statement, he probably will say that he is not exactly sure what he said, since the interview was some time ago. 
It is certainly sound to have the principal, after he is examined, make his own memorandum of the conversation.

Once the agent has concluded his audit, or gets it to the point where he is beginning to pick up issues and to settle down on specific points, the lawyer normally comes into the picture to begin negotiations. At this point, you must make the first really critical decision. Are you going to fully disclose the entire case, giving the agent all the facts and all the law, or are you going to hold some, or all, back? The answer lies in your evaluation, after you have made a thorough investigation of the facts and the law, as to whether this case can be settled or eventually will wind up in litigation. Only with a complete understanding of the facts and a complete familiarity with the applicable law can you make this critical decision. If your decision is to litigate the case, there is not much point in educating the Government by disclosing all of your points of law to the revenue agent. If disclosed, your points will appear in his report and will eventually wind up in the hands of the trial attorney who handles the case for the Government, thus helping him to prepare his case. On the other hand, if your evaluation is that there is a substantial likelihood of settlement, there is no reason to hold back the facts, even at the lowest level. You might as well demonstrate the facts and the law to the agent as strongly as you can at this point, because the easiest point of settlement in a case which does-not involve much money or complicated legal issues is at the revenue agent level.

If you do not settle with an agent, you have the opportunity to have what is termed an "informal conference." You will receive a letter stating that within ten days, if you request it, you may have an informal conference with the revenue agent and a conferee. The old procedure in the Revenue Service was to confer with the agent and his group supervisor. This was a poor system because the agent had normally gone over his proposed findings with his group supervisor, so that frequently the group supervisor was the one who arrived at the conclusions originally. Consequently, you were arguing with the same fellow who had turned you down, although you had not had an opportunity to meet him face to face. Under the present practice, however, you can request and obtain a conference with a conferee other than the agent's group supervisor. Consequently, there is now a slightly better chance of settlement at the informal conference in cases where substantial money or complicated legal issues are involved, since 
the revenue agent would not have wanted to take the responsibility of settling the case himself. Moreover, such a procedure provides some degree of impartiality.

Once the matter has been concluded, either with the revenue agent or with the conferee and you have arrived at a settlement, the agent will proffer form 870 , which is a waiver of restrictions on assessment and collection of tax. But for this waiver, the Government would have to go through a rather formal procedure before the actual tax bill could be issued. ${ }^{10}$ This form waives these restrictions, permits the tax bill to be issued, stops the running of interest, and virtually concludes the case. However, form 870 , as it is presently printed, does not conclude the case as a technical matter. Even though you and the Government have agreed on this form, you are not barred by this sort of waiver and you can sue later for a refund if you are within the applicable statute of limitations. The Government is not barred either, although, as a practical matter, once the Government has accepted this sort of waiver the case is rarely reopened. Form 870 is not the only waiver form used by the Government, and therefore, you should carefully examine the proposed waiver form to determine whether or not your client would be surrendering rights he may wish to assert in the future. ${ }^{11}$

During the course of settlement negotiations on half a dozen issues the Government may suggest that you surrender on two of these and leave the other four for future action. In such a proposed partial settlement, practical considerations are important. If you have an issue on which you are completely licked, there being no question that the facts and all the legal authorities are against you, it is advisable to enter into a partial settlement and give up on those issues so that you can get them out of the way, pay the tax, and stop the running of interest. Instances warranting such action are probably rare, however, because even if the law and the facts are almost all against you, if the issues on which the Government requests a partial settlement have any validity at all, you probably are better advised to hold them for their trading worth. Although they have very little value, they are something with which to trade at a later stage.

Mr. RICE: All this illustrates the importance of getting the attorney

\footnotetext{
${ }^{10}$ Int. Rev. Code of $1954, \S 6212$.

${ }^{11}$ Form 870-AS is very similar in appearance to Form 870, but your client's signature on the former waives his rights to a refund claim.
} 
into a tax case at an early stage. As tax practitioners too well know, they often are not called into a case until it is at the courthouse door.

The next phase of our discussion assumes that the attorney has been called in at any early stage and has not been able to settle the case fully with either the revenue agent or the conferee, and thus he is faced with a 30-day letter. Mr. Isley will discuss this phase.

Mr. IsLEY: The 30-day letter, for our purposes, can be defined as a letter which explains the deficiency to the taxpayer and offers him thirty days in which to make one of three choices: (a) he may agree to the tax. This possibility was ruled out in this discussion when Mr. Fleming failed to reach an agreement at his level; (b) he may file a protest with the District Director in which he requests a conference with the Appellate Division; or (c) he may ignore the 30-day letter and await a 90-day letter which is a statutory notice of deficiency.

In order to understand these possible choices, we need to define two basic terms: protest and Appellate Division. A protest is, for our purposes, a statement of facts, sworn to by the taxpayer, together with a statement of the law on which he relies to support his case. It should be emphasized that this is a sworn statement.*

The Appellate Division is an outgrowth of a special advisory committee which was created in the late I920's to work out an almost impossible backlog of cases pending before the Board of Tax Appeals. Its historical purpose, therefore, is to settle cases. The Division is composed of tax technicians. Some of them are lawyers, many are certified public accountants, and all generally represent the cream of former revenue agents. The Appellate Division is not subservient to the District Director's office. In theory, and to a substantial extent in practice, its purpose is to afford an opportunity to confer on a tax case and to settle that case with some one whose mind is free from the bias which might exist in those who initiated the case. Make no mistake about it, however, the men of the Appellate Division are dedicated government men and any representations or assertions that you make at this level can, and frequently will, be held against you. You must, therefore, proceed with caution.

* Editor's Note: REv. Proc. 61-36, 1961 INT. Rev. Bull. No. 51, at 12, which relaxes the requirement of a protest's being under oath and requires only a certification under penalty of perjury of the truth of the matter stated in the protest, must be considered wherever reference is made in this article to a protest as being a sworn declaration. 
With this background in mind, the problem before us is whether or not to file a protest. The solution involves considerations of tactics and strategy. To determine the tactics and strategy to be employed, it is imperative that we properly evaluate the risks involved in filing a protest, because an improper evaluation can do great harm to our cause. The first risk which comes to mind is that you risk additional review of the facts prior to the issuance of a statutory notice of deficiency. Mr. Fleming referred earlier to a case in which a deficiency increased from $\$ 70,000$ to $\$ 200,000$ simply upon review by the Appellate Division. This is not to say that new issues and increased deficiencies cannot be raised after the issuance of the notice of deficiency. But, in such an event, the Government generally incurs the burden of proof with respect to the newly raised issues. If the new issues are raised by the Appellate Division prior to the issuance of the notice of deficiency, the burden of proof is upon the taxpayer. ${ }^{12}$ Who has the burden is especially important in tax cases, and frequently is the determining factor.

The second risk is that the Government may perfect its analysis of the law involved prior to the issuance of the statutory notice. This is an important consideration, because, under procedures as they exist in the Treasury today, if we file a protest, the statutory notice will be prepared by the tax technicians of the Appellate Division, and it will be thoroughly reviewed for legal adequacy by the Chief Counsel's office. If we do not file a protest, the statutory notice will be prepared by the District Director's office. It will not be reviewed by Appellate, and, absent fraud, transferee liability, ${ }^{13}$ or other complicating circumstances, it will not be reviewed by an attorney. A much litigated question in this area is how far the Commissioner can deviate from the determination in his statutory notice in presenting his case at the trial. Without trying to answer this question, it can be conservatively stated that when the Commissioner tries his case on one theory and the statutory notice on which he proceeds proclaims another, he has at least one strike against him, and possibly three.

A third risk in filing a protest is the possibility, especially in an unusually good factual case, that the Appellate Division will see the weaknesses in its position and send the case back to a field agent for reinvestigation. Frequently, this may result in a settlement with the

\footnotetext{
${ }^{12}$ LORE, HOW tO Win a TAX CASE 50 (1955).

${ }^{13}$ INT. REv. CODE OF 1954, § 6902 .
} 
Government on your terms. However, these reinvestigations sometimes have a peculiar way of opening up a Pandora's box, and what was formerly a simple little tax case can grow until it appears that your client will become a one-man solution to the government's budgetary problems. Proper representation demands that this possibility be evaluated.

A fourth risk is that of committing your taxpayer to factual and perhaps legal positions. Since a protest is a sworn statement, it may be used against him at a later date. It must be remembered that neither the revenue agent's report, the Io-day letter, nor the 30-day letter has a binding effect on the Commissioner, his sole determination being the statutory notice of deficiency. Since the Government, at this stage of the game, has not committed itself, many practitioners believe that they should not commit themselves. In many instances, such a position makes good sense, for many of our tax disputes evolve into the most nebulous of factual areas: questions of intent, whether property was held primarily for sale or for use in a business, whether a transaction was motivated by tax-avoidance purposes, whether a taxpayer was lending to or investing in his wholly-owned corporation. In these nebulous areas, all of the evidence rarely points one way; therefore, it is easy to commit ourselves innocently on matters that will haunt us. It is not unusual for a statement in a protest to be used against a taxpayer which might have been insignificant when written, but as matters subsequently developed, became crucial. Furthermore, by disclosing our case at an early stage in the process, the Government will have more time and thus will be able to combat our factual and legal positions better by doing a more thorough search of the problems involved.

A proper evaluation of the risks outlined does not always require a decision against filing a protest. The first official opportunity to talk with a government man in terms of the litigating hazards of the government's case is at the Appellate Division level, and in a proper case, the full pursuit of settlement possibilities at this level prior to the issuance of a notice of deficiency can accomplish much. If the Government can be shown that it does not have a good case to try, settlement may be possible. Many settlements are made at this level with a minimum of expense, and if a minimum of publicity is an important consideration, filing a protest might be advisable.

In summary, there is no categorical answer as to whether a protest should be filed. Rather, it is a problem which involves a decision based 
upon our client's desires, the advantages to be obtained, and the risks involved.

If the decision is to file a protest, it is important to draft the protest carefully, keeping the principles of good pleading in mind. A protest, of course, is not a judicial pleading, but it is, broadly speaking, a pleading before an administrative body. Usually, the most effective protest is one that is concise and to the point. Again, it should be remembered that the protest is a sworn statement, and a taxpayer should swear to nothing which he is not willing to accept for the remainder of his tax case.

But whether or not we file a protest, there comes a time when we must confer with the Appellate Division and/or the Chief Counsel's Office concerning a settlement. The same principles apply at the conference table in this instance, as apply in any situation where an attorney is presenting a case. A persuasively-presented, systematic analysis of the facts, the law involved and the conclusions to be drawn therefrom, tailored to your individual style are the effective ingredients of any good presentation. Once more, however, we are confronted with the problems of disclosure. This can be done as easily at a conference table as in a protest; however, if we want to settle-and most good lawyers do-we must present the evidence which will form the basis for the settlement that we seek.

There are certain tactics which are basic to a successful settlement conference. All lawyers know the truth of the old axiom "give the judge a peg to hang his hat on." The applicability of this axiom to negotiating a tax settlement at the Appellate Division or Chief Counsel level cannot be overemphasized. Arm yourself with the pertinent Revenue Rulings, acquiesced or agreed decisions and policy statements of the Internal Revenue Service and tie them into a factual analysis of your case. In short, give the technical advisor or government attorney a theory to hang his hat on and provide him with documentation such as books, records, and affidavits; for the government representative with whom you are negotiating must write a detailed memorandum telling his superiors why he settled this case on your terms, documenting all changes in the facts as originally presented.

If your factual theory of a case is dependent upon the oral testimony of the taxpayer or other witness, bringing in the taxpayer or witness to testify before the Appellate Division or the Chief Counsel's attorney should be considered. The use of such testimony in a proper case is 
suggested on the theory that the boldest of trial lawyers, including government men, have some hesitancy when they hear the forceful, persuasive and unimpeachable testimony of a man they will be called upon to cross-examine if and when a trial takes place. Caution must be exercised in the use of this procedure, however. While it can result in an effective presentation in the proper case, it can also do irreparable harm.

An effective presentation of a tax case does little good if you do not make an effective settlement proposal. You must be practical and realistic in your settlement offers. Therefore, a few suggestions should be kept in mind whenever you are considering proposing a settlement.

First, refrain from making so-called "nuisance-value" offers. The government book defines such an offer as one based upon the cost of litigation, and says not to make nuisance settlements. Consequently, if you are so sure of your case that you are willing to concede only the cost of trial, avoid, if possible, phrasing your offer as a nuisance settlement. There have been cases where lawyers have jeopardized a settlement by calling it a nuisance settlement when the same dollar amount they offered would have been accepted on a merit basis.

Second, unless you want a trial, do not insist on the government's concession of an issue on which a strong Service policy prevails against your position, just because you feel you are right. A tax practitioner with such principles inevitably will wind up in the courtroom.

Third, if possible, present your offer in terms of issues, conceding those issues which are against you and obtaining a concession by the Government on those issues in your favor.

Once the issues are set out, it is possible to make an offer in a dollar amount, including or excluding interest to date. When considering this type of offer, however, you should realize that the Internal Revenue Service personnel must undertake the undesirable chore of working back from your dollar amount to the issues which they must justify.

If a case involves issues of law which are undecided or on which a Service policy prevails against you, a settlement frequently can be made by showing that this particular case is not a good one for a test of the Service's theory. Another effective settlement presentation can be made on the basis of a percentage of litigating possibilities or "handicap basis." For example, the government representative may feel that he has a sixty percent chance of winning this case, and thus if sixty percent of the dollar amount involved is offered, the case may be settled. 
Making an offer with the express preamble that "this is our top offer; we are going no higher" is not a wise procedure. Such "top offer" statements frequently become the subject of regret when you realize later that the door to settlement should have been left slightly open. Frequently, the advocate who promiscuously and customarily states a "top offer" gains the reputation among Service personnel of being one whose offer is "top" until he makes another. Of course, if the settlement offer in a particular tax case will serve as a basis for determining the liability for other years or for related taxpayers, there may be a clearly defined limit beyond which you cannot go. Thus, you may want to make it clear that the case must be settled within these clearly defined limits or the case will go to trial. In such a situation, a clearly defined top offer can frequently result in an expedited settlement.

Regardless of settlement technique, the amount of interest should be kept in mind. Internal Revenue Service personnel almost invariably negotiate in terms of a before-interest amount. Thus, in discussing settlement at a figure which includes interest to date, make your terms clear at the outset.

Keeping the terms of your agreement clear is essential throughout all of these negotiations. In a legally and factually complex case one side may misunderstand the overall intentions of the other since each side has its own points of focus. Consequently, an offer made to a technical advisor may seem absurd to him on one or more issues and he may discount its importance. In that event, his written report of the offer may fail to reflect the offer's true substance. Therefore, it is frequently wise, at this level, to reduce your offer to writing so that your terms will be in the report for all to see upon subsequent review, re-examination and possible acceptance.

Another important facet of settlement negotiations is what your rights are after an offer has been made but not accepted. The government book says, in effect, that the Government shall make a counteroffer. Sometimes, however, this rule is not followed because the practitioner fails to pursue his right to a counteroffer, or the Government feels that the taxpayer's original offer was not bona fide and sincere. Good representation usually demands that you actively pursue and request a counteroffer in order to get some idea of the government's "trading range.” 
A recent Revenue Procedure ${ }^{14}$ indicates that the Service and the Office of Chief Counsel are interested in expediting settlements and dispositions of Tax Court cases. The overall purposes of this Procedure are to settle cases at the earliest possible date with a minimum number of conferences, and to determine at the earliest possible date whether settlement is possible and, if not, to begin preparation for trial promptly. To the practitioner, this means that the Government wants you to come into the first conference on a Tax Court case prepared to explore settlement to the fullest possible extent. In large measure, the success of this procedure depends upon the amount of cooperation which practitioners give the Service in its efforts to resolve the case or fix the controverted issues at the earliest possible time.

Another point to remember in presenting a settlement offer is that it is your client-not you-who is going to have to pay the settlement. Therefore, the client must always be consulted before any indication is given as to what will or will not be done. The legal principles involved may not be of interest to him, but how much a settlement is going to cost will be.

If all settlement attempts have been unsuccessful, you are faced with the problem of stipulating facts. In Tax Court cases, the government attorneys will usually contact you and advise that they are prepared to stipulate facts. In sending out notices of trial, the Tax Court advises that the parties should comply with the rules of the court by stipulating facts to the fullest possible extent. This requirement is frequently enforced by a most ungrateful reception when the presiding judge learns that one party has not fully complied with the rule.

The problem of stipulating facts is obviously not unique to tax cases, but it is especially important in tax cases because the circumstances and factual situations are frequently so complex that absent a proper stipulation, trial is almost impossible within a reasonable length of time. Although this workshop does not undertake a thorough investigation of the strategy and tactics of stipulating facts, which is really the first stage of trial, several suggestions in this regard are worthy of special attention.

At the outset, do not underestimate the ability of the young attorney on the other side of the conference table. Government attorneys are,

\footnotetext{
${ }^{14}$ Rev. Proc. 60-18, 1960-2 CUM. Bull. 988.
} 
in the main, capable trial lawyers, and they usually have had extensive experience in tax cases.

Stipulate carefully and only after a complete analysis of the ramifications of the stipulation has been contemplated. For example, if the stipulation of an uncontested fact will relieve the Government of calling a witness from whom you can possibly elicit on cross-examination a favorable fact which is contested, do not stipulate unless the Government agrees to call the witness and turn him over to you on your terms. Likewise, if in a net worth case the Government requests that you stipulate the contents of records of a bank account, the authenticity of which you have no basis to doubt, but the competency of which is questionable, don't stipulate; for regardless of the truth of the matter, your client is entitled to the protection afforded by the rules of evidence.

The problems of materiality and relevancy often arise at a stipulation conference. Lawyers generally do not desire to expose to the adjudicating party, be it judge or jury, uncontested but prejudicial facts which are felt to be immaterial and irrelevant. This problem often can be handled by specifically requesting that the facts which are considered immaterial and irrelevant be the subject of a separate stipulation which will go into evidence only after the materiality and relevancy has been ruled upon by the court.

The problem of whether to stipulate is not always a one-way street, however. On some occasions, the government attorney, for his own tactical purposes, may decline to stipulate those facts which you feel are not fairly subject to dispute. In such an eventuality, there are two possible courses of action. You may amend your petition, alleging the facts in question. If the government's answer does not satisfactorily admit crucial allegations, you may file a motion with the court requiring the Commissioner to show cause why these allegations should not be admitted. Frequently, however, time will not permit this procedure. As an alternative, you can file a motion with the court requiring the Government to show cause why the facts cannot be stipulated. This procedure will result in something akin to a pretrial conference and possibly will put pressure on the Government to stipulate. 'This particular problem frequently occurs in cases where related criminal action is pending.

In the last analysis, stipulations in a complex tax case are a practical necessity. Adroitly handled, they can be most helpful. One page of stipulated facts can frequently replace hours of laborious trial 
and hundreds of expensive pages of transcript. And, more frequently than is realized, two lawyers will emerge from an exhausting stipulation conference having concluded that a settlement, which was previously out of the question, has become the obvious answer to everybody's problem.

Mr. Rice: You of course realize that the decision to file a protest or not to file one and let the 9o-day letter be issued, and then file a Tax Court petition, determines whether you will conduct your negotiations only with the Appellate Division conferee, or with the Regional Counsel representative in the picture. Many tax practitioners feel that settlement possibilities are better if negotiations are made with the Regional Counsel who will have to try the case before the Tax Court. Therefore, they prefer to await the 9o-day letter and then file a Tax Court petition, getting the case in docketed status. However, Revenue Procedure 60-I 8 is considered very important by the Revenue Service and I am sure by the Tax Court also. The Revenue Service has emphasized that this is something that requires the cooperation of the tax bar, and they are asking that cooperation. Revenue officials we have talked to while preparing our comments for this workshop placed quite an emphasis upon the delay of the tax bar and general practitioners in handling tax cases. This is a justified criticism, although it can be explained, no doubt, by "busy lawyers." However, it is not just on one side of the fence, because the Government is often guilty of delay. Another criticism was that many people wait so long to present their case fully. The decision as to when to fully present a case is crucial and was discussed earlier. A fishing expedition at a conference may be justified in some cases, but it does not expedite early settlement of tax cases.

The next phase of our workshop assumes that we have not been able to settle our case at the Appellate Division or Regional Counsel level and a 9o-day letter has been received. Litigation is almost a certainty, and the question arises as to the court in which it is to be conducted. In tax cases, the Tax Court, with headquarters in Washington, D.C., the federal district courts over the country and the Court of Claims, sitting in Washington, D.C., are available. The Tax Court is the only court in which the taxpayer can litigate his liability, and thus determine whether he really owes the tax, without paying it. Before you can start your suit in the other courts, you must first pay the tax, file 
a claim for refund, and wait for it to be disallowed or for a certain period to elapse without disallowance. ${ }^{15}$

In choosing a court, certain considerations must be taken into account. "The first one concerns payment of the tax. Is your client able to pay it, or will this be a tremendous burden or an impossibility for. him? Secondly, is he willing to pay it? The feeling quite often prevails that once the Government gets its hands on money, it's awfully hard to get it back, and for this reason clients are reluctant to pay their tax and then bring suit in the district court or the Court of Claims. A third consideration might be your chance of winning in a particular court. For instance, one of these forums may have a precedent that is quite favorable to your case, or you may have the type of case where a jury trial, which would be available only in the United States district court, is quite advisable. Jury trials are sometimes better in cases involving family partnerships, some types of fraud, depreciation matters, accumulations of surplus and determination of whether money paid into a corporation is an investment or a loan. ${ }^{16}$ Another consideration is who will have the burden of proof. The taxpayer, in most tax cases, has the burden of proof, but the burden is somewhat greater in refund cases than it is in deficiency cases. In a deficiency case, you can win simply by proving that the Commissioner is wrong, but in a refund case, you must not only prove him wrong, but you must show the amount of refund to which you are entitled.

The appellate procedure must not be overlooked. Appeals from the Tax Court or a district court are taken as a matter of right to the Court of Appeals for the particular circuit involved. On the other hand, an appeal from the Court of Claims is possible only on a writ of certiorari from the United States Supreme Court.

The Court of Claims is often ignored in a choice of forums and Mr. Smith is going to briefly outline its setup and procedures.

Mr. Smith: The Court of Claims is a five-judge court which sits, always en banc, in Washington, D.C. The court has thirteen Commissioners, whose principal function is to hear evidence, and these Commissioners will travel anywhere to take evidence.

The initial procedure in the Court of Claims is similar to that in a

\footnotetext{
${ }^{15}$ For a short consideration of some of the problems involved in refund cases, see Smail, Traps in Refund Suits, 39. TAxEs 639 (1961).

${ }^{10}$ See Walston, Use of Juries in Federal Civil Income Tax Cases, 39 TAxes 144
} (196I). 
district court. Once the tax is paid; and the claim for refund filed and disallowed, an action is initiated by filing a petition.

An action in the Court of Claims is defended by the Department of Justice, unlike a case which goes to the Tax Court, where Chief Counsel's representatives defend the case. After the issues are determined by the pleadings, the case is assigned to a Commissioner. The Commissioner, pursuant to various pre-trial procedures requiring the parties to file statements of material facts for admission or denial, tries to bring the parties as close together on stipulations as possible. The case is then set for trial and is heard before the Commissioner. The parties next propose findings of facts, and from these the Commissioner finds the facts, after which briefs are filed. The court then assigns the case for oral arguments before it.

The Court of Claim's jurisdiction is not limited to tax cases. It has jurisdiction in government contract cases of various sorts, such as federal employee pay cases, Indian cases, and any other matters that might be assigned to it by Congress. Its docket generally is relatively clear, depending on how fast the parties are able to get together, and the court in recent years has been able to wind up its year with a minimum of cases left on its docket.

One thing to consider about the Court of Claims as a possible forum for your tax case is the general feeling among tax practitioners that if you have a good case on the technicalities but a weak case on the equities, the Court of Claims is no place for you. On the other hand, if you have a good case on the equities but are fairly weak technically, the Court of Claims might be given serious consideration.

Mr. IsLey: So far, our Workshop has been concerned with non-fraud cases, with emphasis on deficiency cases. Now, we will make briefly and very generally a few observations concerning fraud cases. The handling of tax fraud cases is a field all its own. Tax fraud is very difficult for the Government to prove because, even in civil cases, the Government must show by clear and convincing evidence that the requisite fraudulent intent existed. On the other hand, this is unquestionably a field in which the Government prepares itself well. Fraud cases are investigated by special agents who are skilled specialists in investigating such cases, resulting in a most thorough preparation.

Every step in a civil or criminal fraud case is a calculated risk. If you cooperate, your client may become the government's best witness. On the other hand, if you refuse to cooperate, your lack of cooperation 
can be used as evidence of your client's guilt. Decisions in handling tax fraud cases are delicate decisions, and much has been written on the subject. ${ }^{17}$ There are, however, several general principles to keep in mind in all fraud cases.

First, the only safe rule of thumb is to cooperate only when you are sure that your client is innocent and that his innocence can be demonstrated to the satisfaction of the examining agents. Even here, however, remember that circumstantial evidence can prove guilt and it sometimes has a peculiar way of piling up against a defendant.

Second, remember that disclosure or "tipping your hand," a danger in all tax cases, is more dangerous in fraud cases than any others. In a criminal fraud investigation, the Government literally will not give you the "time of day." They will tell you nothing about what type of income they are computing, how they are computing it or anything else. You and your client are kept totally in the dark, and the taxpayer's every misstatement, regardless of vagueness of memory or any other excuse, becomes a potential threat to his credibility. In any civil tax case, including fraud cases, you are entitled to know, in reasonable detail, the Government's computation of income. This includes, generally speaking, the method of computation utilized as well as the figures on which the computation is based. If all else fails, you may obtain this information by a motion in the Tax Court to have the Government make more definite and certain the allegations of fraud.

Third, it is important to understand the law governing the method used to reconstruct your client's income. Each method, whether net worth, bank deposits, percentage mark-up or some other, has its. idiosyncrasies and individual requirements of proof. If possible, show that the method used was improperly applied to your taxpayer's case, on either the law or the facts.

Fourth, remember that your client's constitutional privileges, including those against unreasonable search and seizure and self-incrimination, extend to tax fraud cases. ${ }^{18}$ However, a civil fraud case should

${ }^{17}$ During the Workshop, Mr. Rice mentioned two of the more widely used books in this area. Kostelanetz \& Bender, Criminal Aspects of Tax Fraud Cases. (1957); Mortenson, Federal Tax Fraud Law (1958). For a review of fraud prosecutions, see Balter, Ten Year Revierw of Fraud Prosecutions, N.Y.U. I9th Inst. on Fed. Tax II25 (196I). For recent discussions concerning representation of a taxpayer in a tax fraud case, see Heckerling, Tax Fraud Investigations: Cooperative or Adversary Proceedings?, 39 TAxes 807 (196r) and Lipton, Taxpayer Under Fraud Investigation: Suggestions for Effective Representation, 47 A.B.A.J. 265 (1961).

${ }^{18}$ Note, Constiutional Aspects of Federal Tax Investigations, 57 Colum. L. REV. 676 (1957). 
not be confused with a criminal case. At a civil fraud trial, a taxpayer refrains from testifying at his peril, because there is an inference that had he testified, his testimony would have been unfavorable. In a criminal fraud case, no such inference is permissible.

Fifth, in a civil tax fraud case, there is a possibility of requiring the Government to present its case first. Unlike non-fraud cases where the taxpayer is almost invariably required to proceed first, the Government must proceed first in fraud cases unless other questions, such as a dispute over the amount of income, are involved.

If the amount of income is in dispute, the amount might be stipulated, thus placing the Government in the position of having to proceed with their case first because all that remains in issue is the fraud penalty. If a decision is made against such stipulation, the taxpayer's case might be greatly harmed, because the Government, in proving its case on the amount of income, may subject the taxpayer's credibility to serious doubt, or it might become apparent that the taxpayer is extremely intelligent and not likely to have inadvertently made mistakes resulting in the deficiency in question. In other words, if the amount of the deficiency remains in dispute, your case with respect to the disputed item will sometimes jeopardize your case with respect to the fraud issue.

On the other hand, agreement as to the amount of income involves certain adverse consequences. Once you stipulate the amount of income, you admit one of the elements of fraud-an understatement of income. However, if you can come forward with an explanation for the understatement which is compatible with innocence and is convincing, there is no reason why it would not be good strategy to stipulate the entire amount of income, leaving only the fraud issue in dispute. Forcing the Government to proceed first is usually a substantial advantage.

Sixth, one should understand and be able to recognize what the government men call the "badges of fraud." These badges of fraud are elusive and many a practitioner has sat innocently by while the record was being filled with what the courts consider circumstantial evidence of fraud.

Seventh, if necessary, invoke the rules of evidence at every reasonable opportunity. The rules of evidence in tax fraud cases, with their tremendous emphasis on intent, and the mass of documentary evidence, are especially important, and the successful exclusion of one important link in the government's chain of proof often can mean the difference between success or failure. 
Eighth, in the trial of a fraud case, the Government may invoke the rule excluding all witnesses from the courtroom until called to the stand. This procedure is to prevent the taxpayer and his friends from ganging up on the Government. However, don't overlook the possibility of invoking the rule to exclude the government's witnesses, several of whom are possibly the agents on whom the trial attorney is relying for his information. From personal experience, I can assure you that this is a terrible spot for the Government attorney to be in. ${ }^{10}$

Mr. Rice: It is, of course, true that the Revenue Service will not discuss with you the question of the civil tax liability as long as there is a consideration of criminal prosecution. They want to dispose of the criminal liability before they will even talk about the civil liability. However, if you desire, there will be many opportunities to represent your client before the Revenue Service and the Justice Department to convince them that they do not have a case which they can successfully prosecute.

${ }^{29}$ In answer to a question concerning the merits of using a recording device at the oral interviews during a fraud investigation, $M r$. Isley concluded that a recording might be very beneficial in preparing for trial. However, he stated that he had never heard of a case where a recording of this nature had been made. 